\title{
THE EMOTIONAL PROSODY OF U.S. FATAL AIR-ACCIDENT DOCKETS ONLINE: RISKING RISK COMMUNICATION?
}

\author{
Carmen Sancho Guinda \\ Universidad Politécnica de Madrid \\ ETSI Aeronáutica y del Espacio \\ Plaza del Cardenal Cisneros 3 \\ 28040-Madrid, Spain
}

\begin{abstract}
Risk communication is grounded in both rationality and emotion (Fischhoff $\&$ Kadvany 2011, Boholm \& Corvellec 2014). Recent investigations have proved that emotions do affect risk and danger perceptions by functioning as 'mediators' (Xie et al. 2011) and become important in decision-making. My study explores how emotion is induced by the National Transportation Safety Board of the United States of America (NTSB for short) to influence the mentalities and behaviours of its broad mixed audience and thus increase risk prevention. With that research purpose in mind, I examine an electronic corpus of over 500 online samples of fatal aviation dockets issued yearly online by the NTSB between the time span 2010 2015 and contained in its website databases. The emotional engagement deployed to mediate the perceptions of risk and danger by the general public constitutes a unique genre among all other world transportation agencies, since through informative vividness it pursues to activate the processes of memory, inference (i.e. judgement) and decision-making.

I take Stubbs' (2001) concept of 'discursive prosody' as point of departure and resort to a blended theoretical framework that combines Narratology, Corpus Linguistics, Critical Discourse Analysis, and Proximisation (Cap 2013) and Positioning (Harré \& van Langenhove 1999) Theories. I will show that the NTSB's emotional prosody is more rhetorical than lexical and that the narrative strategies of focalisation and speech representation play a salient role. To conclude I will reflect on some of the possible consequences of over-exploiting emotional engagement in risk communication.
\end{abstract}

Keywords: Risk communication, emotional prosody, proximisation, positioning, narrative focalisation, aircraft-accident dockets online, U.S. National Transportation Safety Board

\section{THE EMOTIONAL BACKGROUND OF RISK COMMUNICATION}

Although the prevention of hazard is driven by emotion as much as by rationality (Fischhoff \& Kadvany 2011, Boholm \& Corvellec 2014) and recent research (Xie et al. 2011) has demonstrated that emotions function as 'mediators' influencing the perception of danger and the making of related decisions, emotional language is not expected in risk communication (henceforth RC), let alone if the text in question is a synopsis issued by a corporation or a governmental organism. Counter to these expectations, however, many of the dockets or synopses of aviation accidents disseminated online every year by the National Transportation Safety Board of the United States of America (NTSB for short) exhibit a distinctive 'emotional tone' that notably diverges from the sanitised technical style of other world transportation agencies. This study explores the motivation for such a stylistic singularity as well as the concrete strategies with which it is realised and confer the genre a unique quality hybrid between informative journalism, technical 
report and entertainment storytelling. Elsewhere (Sancho Guinda 2015), I have termed this discursive blend 'catastropop', a popularisation of the technical reporting of catastrophe which currently borders upon 'hybridisation' (Fairclough 1993, 2006), 'genre bending' (Bhatia 2004), and 'genre innovation' (Tardy 2016). In a similar vein but from a multimodal perspective, this hazy discursive status has been detected and investigated by Zhang and O'Halloran (2014) in the science news disseminated in institutional and mass media websites ${ }^{1}$. Posed more directly, my research question is the following: What discursive traits underlie the emotional tone of NTSB air-accident dockets?

By its very nature, RC carries a heavy emotional load. Maynard's (2011) blunt and humorous definition of risk ("Risk = OMG x WTF!") suggests that RC is aroused by a triad of emotion pairs at play: 1) curiosity and/or surprise about the causes of a certain mishap (actual or hypothetical), which calls for enough anticipation for prevention; 2) anger at its aftermath or at the negligence of the person(s) in charge, and/or fear of disaster recurrence; and 3) a need for control over the potential or consummated risk, and/or for trust in the experts and institutions exerting such control.

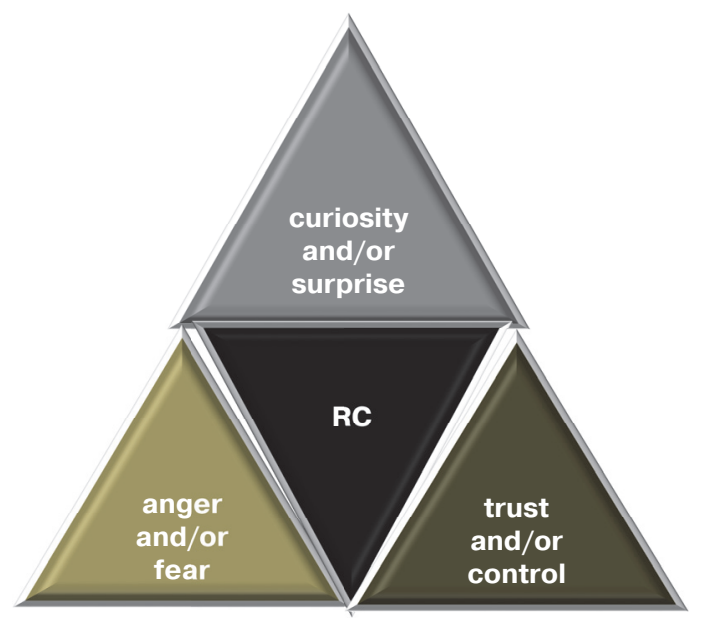

Fig. 1: Emotional components of RC as deduced from Maynard's definition

The polar opposites surprise/anticipation, fear/anger and trust/distrust form part of Plutchik's (1980) list of basic emotions, and anger, fear and surprise are also primary for Shaver et al. (2001). By contrast, Bednarek (2008a) does not consider trust and surprise basic emotions but separate areas of affect that constitute subcategories of (in)security, related to an 'ecosocial well-being' (Martin \& White 2005: 49). Curiosity is for Bednarek an emotion concerned with 'telos' (Martin \& White 2005: 49); that is to say, with the pursuit of a goal, an aspect stressed as well by other authors such as Watt Smith (2015: 65) in The book of human emotions: "Without curiosity, it's hard to imagine creativity or invention at all". This researcher reminds us that curiosity gave rise to the scien-

${ }^{1}$ To qualify the hybrid discourse of the genre object of their study, these scholars coined the designation 'scifotainment', a blend of scientific information and entertainment. 
tific method, and that in the form of gossip it allows ideas to travel and enhances a sense of community. But, which community do we mean? Because, while for boards investigating accidents curiosity is supposed to be prompted mainly by the need and the duty to find out causes (technical failures, human factors and organisational deficiencies) and recommend appropriate safety measures for the future, the trigger may not be so straightforward for the general public, whose feelings could rather be labelled as 'morbid curiosity' (Watt Smith 2015: 180). This variant of curiosity may occur either due to the cathartic effect of knowing of other people's misfortunes, to an inbuilt reflex for expressing empathy and strengthening social bonds, or to the desire to familiarise ourselves with catastrophe and become capable of coping with it. There is, in addition, another element that may impel us to feel (morbid) curiosity about aviation disasters: their extremely low frequency.

In effect, together with their unexpectedness, their dramatic intensity, and their meaningfulness (i.e. in our globalised world, massive tragedies transcend space, interrupt time, question ethical issues and create a sense of 'transnational community'), what makes air accidents so reportable is that they are extraordinary one-off events, which makes them incontestably newsworthy. According to the International Civil Aviation Organization (2006), known as ICAO, out of six hundred aviation incidents (which may consist of just nuisances, operation limitations or the activation of emergency procedures), only one will turn out to be fatal (causing deaths and destroying equipment), whereas ten will be serious (involving injuries to people and material damages) and thirty only minor accidents (resulting in lesser injuries and reductions in safety margins due to work overload and inaccurate or incomplete operations). It is assumed that behind any instance of RC there is institutional trust on the part of the citizenship, who believes not only in the competence of the organism in question to handle the extraordinary, but also in its goodwill and trustworthiness and transparency as a source of information (Hawley 2012, Neeley 2014). In other words, the audience must take the institution's credibility for granted regarding expertise, intention and reliability, and keep confident that through commitment and cooperation certain future events will occur as expected (Hawley, 2012, Besley \& McComas 2014, Tuler \& Kasperson 2014) and thus safety will prevail.

\section{THE INSTITUTIONAL AND PROFESSIONAL CONTEXT OF NTSB AIR-ACCIDENT DOCKETS}

It is precisely this principle of institutional trust and transparency that rules the NTSB's online mission statement, published in its website (example 1, my italics):

(1) Staff in the NTSB's Freedom of Information Act (FOIA) office process hundreds of FOIA requests every year. Their work is their passion and they take great pride in ensuring that the agency is open and transparent to the American public. Since July 1, 2009, the NTSB has been proactively posting public docket information on the accidents and incidents investigated by the Safety Board. On average over 130 dockets are posted to the public website each month and in response to customer requests the NTSB has introduced upgrades to facilitate the searching of the docket database and to identify dockets that have been recently updated. 
Thanks to the legal framework set by the FOIA, then, NTSB aviation-accident dockets are made accessible in a public website whose systems of storage and retrieval are periodically upgraded. The intended audience is broad and mixed since it joins experts and laypeople: it comprises other agencies investigating accidents worldwide, the ICAO and rest of national and international aviation authorities, national aviation associations, aviation professionals (crews and maintenance personnel), aircraft and engine manufacturers, insurance companies, law professionals, scholars and universities, victims and their families, and the press. A large sector of this ample readership requires popularisation strategies to be reached, a difficult premise because the text results from collaborative expert writing endeavour, as authorship is shared by the NTSB's field researchers and their teams of colleagues and proofreaders in successive rounds of revisions until it is finally issued. Hence the information provided necessarily becomes a blend of contents and their corresponding registers: on the one hand, purely technical information referred to expert analyses of the terrain and wreck remains, aerial photographs and cabin voice recordings. On the other, personal stories and accounts elicited from the crew (in interviews or obtained from cabin voice recordings) and the aviation staff involved, witnesses, and victims and their families. Sifting the narratives from both realms, a body of legal literature (e.g. protocols, procedures, standards and regulations) may be originated, and so a 'narrative network' (Bearman et al. 1999) arises across the technical, personal and legal fields.

As for the docket format, it is similar to that of any conventional scientific abstract, with a variable extension from 100 to 400 words. It is composed of two major parts (example 2, all emphases mine): a series of headings summarising the accident circumstances (e.g. identification code, date, place, filing data, aircraft type and model, aftermath) and the body of text, which fuses the traditional four-move IMRD structure (INTRODUCTION $>$ METHOD $>$ RESULTS $>$ DISCUSSION) of scientific narratives (Swales 1990) and the Labovian sequence (ABSTRACT $>$ ORIENTATION $>$ COMPLICATING ACTION $>$ RESOLUTION $>$ CODA) of personal narratives (Labov \& Waletzky 1967). Throughout either of these narrative stages, attribution (marked with italics in the docket sample below) becomes the backbone that holds the whole structure together, so that the information is sequenced in a growing degree of objectivity: WITNESSES' TESTIMONIES > EXPERT ANALYSIS > EVIDENCE > BOARD'S CONCLUSIVE VERDICT.

(2) NTSB Identification: ERA10LA431

14 CFR Part 91: General Aviation

Accident occurred: Wednesday, August 18, 2010 in Old Forge, NY

Probable Cause Approval Date: 11/17/2011

Aircraft: MAXAIR MU 582 DRIFTER, registration: N582RH

Injuries: 1 Fatal, 1 Minor.

NTSB investigators may not have traveled in support of this investigation and used data provided by various sources to prepare this aircraft accident report.

According to the passenger, the pilot had planned to fly the airplane to the opposite end of the lake. He said that the pilot taxied about $3 / 4$ of the way down the lake, turned around, and started the takeoff roll. The airplane began to climb within 300 feet, but the pilot noticed an approaching line of trees on the shore, so he banked the airplane steeply to avoid hitting the trees. The passenger said that, when the pilot banked the airplane, all 
forward momentum was lost and they seemed to freefall. The passenger estimated that the airplane fell to the ground from a height of about 100 feet and impacted a swamp in a nose-down attitude. He said that the engine continued to operate throughout the entire accident sequence. A postaccident examination of the engine revealed no evidence of any preimpact mechanical malfunctions or failures.

The National Transportation Safety Board determines the probable cause(s) of this accident to be:

The pilot's failure to use the full length of the lake, which necessitated a steep

turn to avoid obstacles during takeoff that resulted in an accelerated stall.

Full narrative available

Added to all these constituents, there may appear elements imported from drama and storytelling, such as dialogues, climactic build-ups, and in medias res narrative openings ${ }^{2}$. Consequently, NTSB dockets are 'interdiscourses' or 'discursive hybridisations' (Fairclough 2006, Berkenkotter, Bhatia \& Gotti 2012) that moreover merge different reporting styles (direct testimonies and indirect speech), features of oral (e.g. onomatopoeias, conversations) and written language (e.g. overall formality), objectivity and subjectivity, retrospection and prospection, and informative, prescriptive and performative functions - the latter through formulaic language that carries out the speech act it enunciates (as in "The National Transportation Safety Board determines the probable cause(s) of this accident as follows:..."). In amalgam with the unusual emotional tone, this performativity makes NTSB dockets stand out in their genre from among the other world transportation agencies, which employ a less detailed and vivid style and non-performative verbs in the past simple to express final verdicts (e.g. the United Kingdom's $\mathrm{AAIB}^{3}$ formula "The investigation identified the following causal/contributory factors...").

Yet the inclusion of multivocality in dialogical form and of climactic non-linear narratives is not whimsical, as it purposely complies with the elementary FOIA principle of communicative transparency, which agglutinates the subprinciples of accessibility and informativeness. As said, the first is met by the proactive online dissemination monthly undertaken by the NTSB in its webpage and by the explicitness achieved by means of a wide array of devices: metadiscursive glosses and overt markers of inference often superfluous to expert readers, footnotes with additional explanations, hyperlinks leading to a constellation of complementary genres (e.g. the full technical report, associated legal documents, multimodal animations rendering the accident, slideshows on a particular aspect of the disaster, such as its environmental impact, etc.), and by the memorability of the storytelling format present in many synopses. In this way the message is made intelligible for lay audiences and easy to retain. The second subprinciple, informativeness, is fulfilled by fine-grained detail disclosure and multivocality, which, besides ensuring a more democratic reporting through co-constructed narratives, instills greater precision than a mono-focalised recount by a single omniscient narrator, and

\footnotetext{
2 An in medias res opening is the absence, while reporting, of a narrative frame for actions, which are recounted as already in course in the middle of the plot.

3 The acronym AAIB stands for 'Air Accidents Investigation Branch'.
} 
impinges on the institution's credibility by depicting it as a flexible authority. In such depiction, the multiple voices of the co-narrators allowed coalesce in the end to corroborate and reinforce the Board's final verdict. Put more simply, multivocality nurtures the citizeship's trust in the organism's expertise, power, and democratic spirit. For these reasons, it may be regarded as a tool for political branding.

Depending on the accident aftermath, the NTSB classifies its dockets into fatal (causing deaths), non-fatal (causing injuries) and incidents (with just technical repercussions), and, according to the investigation stage, into preliminary (reporting still at an early phase), factual (providing data but not speculating on causes, mostly because a foreign government is in charge of the investigation), and of probable cause (speculative as to the causes of the accident and the ethics of the actors involved, normally the crew and maintenance personnel). I have focused my study upon fatal probable cause samples, under the assumption that, owing to their completeness, speculative nature and the seriousness of the accident outcome, they should be more emotional in style than the other docket types.

\section{METHODOLOGY}

Although computerised search has been conducted, this study is essentially qualitative and draws on the manual scrutiny of an electronic corpus of 517 NTSB docket samples online covering the time span 2010-2015, all of them belonging to the fatal and probable cause types and retrievable from the website www.ntsb.gov/_layouts/ ntsb.aviation/month.aspx. They total 182,708 tokens and 7,356 word types.

My theoretical framework is an eclectic one merging Narratology (Bal 1985, Czarniawska 2004, Elliott 2005, Andrews, Squire \& Tamboukou 2008, Kohler Riessman 2008), Critical Discourse Analysis (Bloor \& Bloor 2007, Chouliaraki 2008, Machin \& Mayr 2012) and the Proximisation (Cap 2013, Zwickle \& Wilson 2014) and Positioning (Harré \& van Langenhove 1999) Theories, the last two of vital importance for articulating the points I make in this article. Leaning on Proximisation Theory, I contend that the three strategies examined here and that make up the emotional tone characteristic of NTSB dockets - namely narrative openings, detail disclosure and direct speech reporting to render dialogue between narrative actors - serve to reduce spatio-temporal and social psychological distance in order to approach the risk to the addressees of the RC. Following Positioning Theory, I argue that the NTSB adopts fluid roles to construct its stance towards the message and its audience: those of governmental authority, expert knowledge and emotion mediator, and fellow citizen. Furthermore, to pinpoint the emotional features in my samples, I have taken Stubbs' (2001) concept of discursive prosody as point of departure.

Like 'semantic prosody' (Xiao \& McEnery 2006) or 'semantic preference' (Bednarek 2008b), 'discursive prosody' refers to recurrent attitudinal meanings, usually pragmatic and accomplished via collocational phenomena, but goes beyond single words to attend to the relationships between larger chunks of the message and their context. Bearing in mind Bednarek's (2008a: 132) caution that prosodies are partly intuitive and not always objectively derived from corpus evidence, I first operated on a semantic level 
and skimmed through my corpus noting down those expressions that I deemed to convey or stir emotion. Subsequently I brainstormed a list of other reasonably expectable lexical items, sorted them out as to their likely effects on the reader, and proceeded to search for their most frequent collocations electronically (see data tables in the findings section) with the freeware concordancer AntConc 3.1.w (Anthony 2007). This electronic search of brainstormed expectable items was intended to cover more lexical ground and complement the previous examination with the naked eye, so as to get a bigger picture of the weight of emotional vocabulary in the samples' overall tone. At a last stage I tackled another manual inspection of the corpus, during which each sample underwent the following procedure:

- Examination of narrative opening (whether conventional framing of actions or in medias res)

- Detection of direct speech reporting and interpretation of functions

- Analysis of remarkable detail use

The fundamental reasons for scutinising these discursive features and not others have been these: first, their conspicuity (they meet the eye and distinguish NTSB dockets from those of any other transportation agency round the world); second, their structural nature (rather than being mere lexical choices they organise the message); third, their size (as all of them are larger than the sentence); and fourth, their variable frequencies (while in medias res openings are massive, the other two strategies seem to appear in a much more reduced number of samples). The size factor has been decisive to discard the application of the Appraisal System model, more fitting for categorising textual items as big as the sentence or smaller.

\section{FINDINGS: THE SYNERGY OF DISCURSIVE PROXIMISATION STRATEGIES}

Contrary to what might be thought, the incidence of 'potentially emotional' lexical items in the corpus is rather low. Their occurrences are shown in Tables 1, 2 and 3, in which the words searched are grouped according to their probable perlocutionary effects: Table 1 gathers terms that might be considered 'gruesome' or likely to cause fear and/or disgust, Table 2 displays words that transmit or arouse empathy, and Table 3 shows potentially biasing terms, likely to condition the reader's opinion on the actors' behaviours. It could be argued that some of the words classified under a category might also belong to another, as is the case of 'sickness' and 'illness', which might evoke repulsion besides arousing empathy with victims or exonerating crews from guilt, or of 'suicide', which in addition to blaming pilots might suggest repulsion too. These alternative semantic associations, though, have not been found in any of the corpus examinations, electronic or manual. The minimal impact of emotional lexis has made me dispense with n-gram searching and opt for not normalising individual items, as I consider raw counts more telling and immediate. I have just normalised (per 1,000 words) the totals under each category. Some of the counts correspond to items from the same lexical family (e.g. pain, painful, or death, died and die), and their electronic search results have been displayed together and not separately because of the low number of hits. 
Lexical items likely to cause repulsion

\begin{tabular}{|l|c|l|}
\hline \multicolumn{1}{|c|}{ 'GRUESOME' ITEMS } & RAWFREQUENCIES & \multicolumn{1}{c|}{ MAIN COLLOCATES } \\
\hline Blood & 56 & Test, sample, level, alcohol, pressure, sugar \\
\hline Crash & 41 & Site, fire \\
\hline Post(-)mortem & 30 & $\begin{array}{l}\text { Toxicology/toxicological testing/analysis, } \\
\text { sample(s), examination, production, pro- } \\
\text { duced, redistribution }\end{array}$ \\
\hline Tissue & & Specimen, samples \\
\hline Pain(ful) & 14 & $\begin{array}{l}\text { Back, spinal, severe, chronic, intermittent, } \\
\text { spider bite }\end{array}$ \\
\hline Risk & 14 & High, significant, serious, own \\
\hline Burned & 13 & Not applied to people \\
\hline Death/died/die & 11 & $\begin{array}{l}\text { Death: after, cause of, cardiac, passengers } \\
\text { Died: of, at, from, in }\end{array}$ \\
\hline Crushed & 10 & Fuselage, pieces, parts \\
\hline Fatally & 8 & Injured, injuring \\
\hline Putrefaction & 6 & Specimen(s), postmortem, presence of \\
\hline Catastrophe/catastrophic & 3 & Failure \\
\hline Danger(ous) & 2 & Potential \\
\hline Coma & 1 & Put (him) in \\
\hline Drown(ed/ing) & 1 & Passenger \\
\hline $\begin{array}{l}\text { TOTAL } \\
\text { NoRMED TOTAL (per 1000 words) }\end{array}$ & 1 & \\
\hline brainstormed items not found & $\mathbf{2 1 1}$ & $\begin{array}{l}\text { Disaster, fatalit(y/ies), threat, corpse(s), } \\
\text { hemorrhag(e/ic), wound(s), deceased, } \\
\text { victim(s), suffocat(e/ion/ing) }\end{array}$ \\
\hline & 0 & \multicolumn{2}{|l|}{} \\
\hline
\end{tabular}

Lexical items likely to cause empathic responses

\begin{tabular}{|l|c|l|}
\hline \multicolumn{1}{|c|}{ 'EMPATHY-AROUSING' ITEMS } & RAW FREQUENCIES & \multicolumn{1}{c|}{ MAIN COLLOCATES } \\
\hline Disease & 34 & $\begin{array}{l}\text { Heart, lung, artery, cardiac, coronary, } \\
\text { cardiovascular }\end{array}$ \\
\hline Child & 13 & Passenger(s), weight, foot \\
\hline Wife & 8 & Reported, stated, was \\
\hline Sick(ness) & 2 & Getting/got \\
\hline Illness & 2 & Underlying, depressive \\
\hline School & 1 & Yard \\
\hline $\begin{array}{l}\text { TOTAL NORMED TOTAL (per 1000 words) } \\
\text { NOR not found }\end{array}$ & $\mathbf{6 0 . 3 2}$ & $\begin{array}{l}\text { Infant, baby, girl, boy, teenage(r), young, } \\
\text { youth(s), juvenile, elderly }\end{array}$ \\
\hline brainstormed items nom & 0 &
\end{tabular}

Lexical items likely to influence the reader's judgements of actor behaviour

\begin{tabular}{|l|c|l|}
\hline \multicolumn{1}{|c|}{ 'BLAMING' ITEMS } & RAW FREQUENCIES & \multicolumn{1}{c|}{ MAIN COLLOCATES } \\
\hline Pilot('s/s') failure & 109 & $\begin{array}{l}\text { To maintain (84), to abort, to use, to divert, } \\
\text { to obtain, to apply, to preflight, to retrim, to } \\
\text { monitor, to clear, to secure, to correct, to } \\
\text { attain, to take, to see, to anticipate, to achieve }\end{array}$ \\
\hline Alcohol & 40 & Level, consumption, ingestion, concentration \\
\hline Ethanol & 27 & $\begin{array}{l}\text { Found, identified, detected, use, positive for, } \\
\text { presence of, metabolism }\end{array}$ \\
\hline Drug(s) & 18 & $\begin{array}{l}\text { Singular: prescription, use, screen results, } \\
\text { dependence, assays, quantities } \\
\text { Plural: evidence of, detected, redistribution, } \\
\text { multiple, performance-impairing }\end{array}$ \\
\hline
\end{tabular}


End of the table 3

\begin{tabular}{|l|c|l|}
\hline \multicolumn{1}{|c|}{ 'BLAMING' ITEMS } & RAW FREQUENCIES & \multicolumn{1}{c|}{ MAIN COLLOCATES } \\
\hline Marijuana & 17 & Use, abuse, metabolite \\
\hline Over-the-counter & 13 & $\begin{array}{l}\text { Medication(s), antihistamine, cough sup- } \\
\text { pressant }\end{array}$ \\
\hline Narcotic(s) & 13 & Medicaton(s), painkiller(s) \\
\hline Dependen(t/ce) & 6 & Drug, nicotine, abuse or..., substance \\
\hline Suicide & 4 & Note \\
\hline Opioid(s) & 3 & Narcotic, use \\
\hline Beer & 3 & Bottle, container, six-pack \\
\hline Tetrahydrocannabinol & 3 & Presence of, positive for \\
\hline Bourbon & 2 & Bottle \\
\hline Barbiturate(s) & 1 & Prescription \\
\hline Bottle & 1 & Bourbon \\
\hline $\begin{array}{l}\text { TOTAL } \\
\text { NORMED TOTAL (per 1000 words) }\end{array}$ & $\mathbf{2 6 0}$ & \\
\hline brainstormed items not found & $\mathbf{1 . 4 2}$ & $\begin{array}{l}\text { Conceal(ment/ed), foolhard(y/iness), irre- } \\
\text { sponsible, irresponsib(ility/ly), neglect(ion), } \\
\text { ignor(ant/ed/ing) disregard(ed), ne- } \\
\text { glect(ion/ed), pills, boast, brag, show off }\end{array}$ \\
\hline
\end{tabular}

Results show that the category of 'blame' (predominantly applied to the pilot or other members of the crew) has yielded the highest number of hits: 1.42 every 1,000 words. This is expectable because, according to the ICAO (2006), a huge percentage of accidents (around 70\%) is caused by human failures attributable to the pilot, and, in consequence, items referring to substances and habits forbidden or disapproved of by the ICAO are supposed to abound. Next, words describing the accident scene or events and that might be perceived as 'gruesome' by the audience, form the second most numerous category of emotional vocabulary: there are 1.15 every 1,000 words. This fact can be explained by the very nature of the document under study - the accident docket: it must include important data (from the accident scenario and the reconstruction of the accident) to speculate about possible causes and eventually issue a verdict. We may observe that the collocates of emotionally loaded words such as 'blood', 'post-mortem', 'crushed', 'putrefaction', 'catastrophe', etc., are neutral words from technical fields in the accident investigation, which connote efficiency and expertise rather than repulsion. Lastly, the least frequent category is the one comprising items potentially arousing empathy with any of the actors in the accident narrative (the pilot and the rest of the crew, witnesses, or victims). Their rate of occurrence is quite low: 0.32 per 1,000 words, and with the exception of items such as 'disease', 'sickness', or 'illness', often related to objective causes of the accident via toxicological and pathological tests (and therefore necessarily included in the docket), the rest of terms (e.g. 'wife', 'child', etc.) refer to more peripheral details that help reconstruct the course of the accident events with accuracy.

Let us now turn to the three discursive strategies most used in the corpus to raise emotion with a view to approaching the risk to the heterogeneous audience of the NTSB. Figure 2 evinces the overwhelming frequency of in medias res narrative openings, presumably because of their multi-functionality as attention getters that encourage to read on, 'proximal resources' that bring the risk closer to the addressee and vice versa, amusing suspense-builders that set the scenes prior to the accident denouement, and mne- 
monic helpers that may make the content more memorable than any factual recount. These openings also communicate a greater deal of information, given that the introductory headers at the top of the document already contain the accident's basic facts and fulfill the framing function of a linear narrative. In medias res beginnings may refer to events previous to the accident (past reference) - for instance to actions performed by the crew or the maintenance personnel in the previous hours, days, weeks or months, to the reporting by witnesses and experts some time after, as a sort of 'flashback', or to a span of time in which the mishap is about to happen. This last alternative is the most engaging one, due to its fictional 'thriller-like' climactic quality and its creation of a mysterious atmosphere that captures the addressees' interest. Examples 3, 4 and 5 respectively offer a contrast between one of those 'thriller-like' in medias res openings, a more conventional in medias res start, and a simple linear framing.

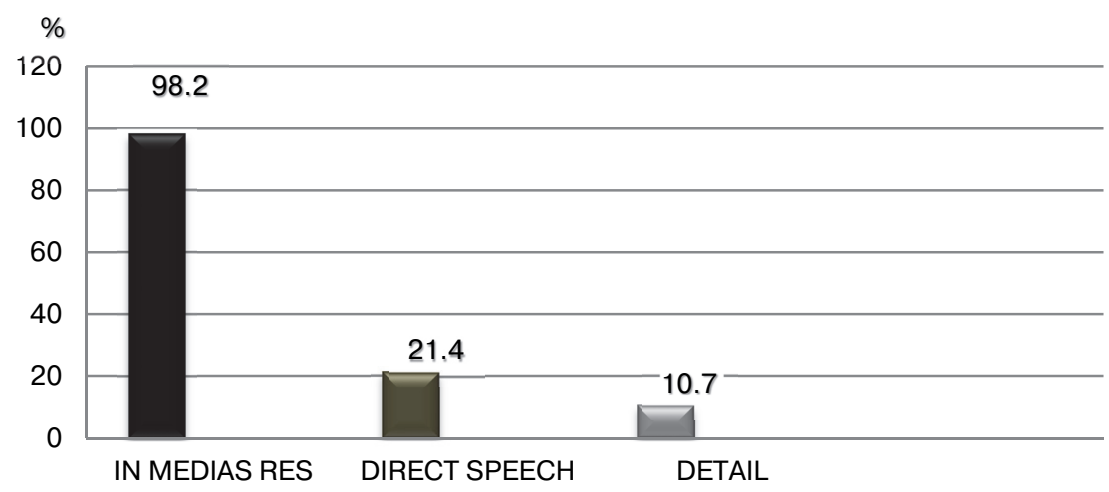

Figure 2. Discursive proximisation strategies (percentage of docket samples)

(3) The pilot and the two passengers departed on a cross country flight on a dark, moonless night over a rural area. Approximately 10 minutes after they departed, the airplane was observed in a descending spiral over a hay field. The last 50 seconds of recorded GPS data and the witness's description of the maneuvers before the crash were consistent with the pilot experiencing a vestibular illusion, which resulted in a spiral from which he was unable to recover. (...) [NTSB Identification: CEN10FA392]

(4) The pilot and passenger were on the final approach to their destination airport, after completing about a 550-nautical mile, cross-country flight in a kit-built airplane. During the approach, the left wing dropped and the airplane entered a steep descending bank before impacting the terrain. (...) [NTSB Identification: CEN10LA274]

(5) On August 9, 2010, about 1442 Alaska daylight time, a single-engine, turbine powered, amphibious float-equipped de Havilland DHC-3T airplane, N455A, impacted mountainous, tree-covered terrain about 10 nautical miles (nm) northeast of Aleknagik, Alaska. The airline transport pilot and four passengers received fatal injuries, and four passengers received serious injuries. The airplane sustained substantial damage, including deformation and breaching of the fuselage. The flight was operated by GCI Communication Corp. (GCI), of Anchorage, Alaska, under the provisions of 14 Code of Federal Regulations Part 91. (...) [NTSB Identification: ANC10MA068] 
The other two discursive strategies of proximisation, direct speech multivocality and detail disclosure, go hand in hand and their impact is ostensibly minor than that of in medias res narrative openings, even though their mere presence in a technical document of this kind is remarkable in itself. Direct speech quotations perform the functions of in medias res openings (i.e. grab and sustain the readers' attention and immerse them in the accident context, aid memorization, and introduce more precise information) and several more, among which are the following:

a) Build rapport and intimacy through a conversational, occasionally even gossipy tone that may uncover private personal information (chiefly medical, penal and sentimental) to understand the behaviour of crew and aviation personnel members. Sometimes NTSB dockets include conversation snippets from cabin voice recordings, as in (6). In these cases, the recount takes on a dramatic tinge that may turn helpful to remember accident causes and necessary long-term routines.

(6) In the minute preceding the descent, a transmission from the airplane that included the words "mayday mayday mayday" and "[I] have a flight control malfunctions looks like I'm going down" was broadcast, and the airplane transmitted the emergency transponder beacon code. (...) [NTSB Identification: ERA10FA346]

b) Simplify technical concepts by creating didactic similes or supplying known schemata to categorise new phenomena. In this sense, the sui generis onomatopoeias and comparisons in witnesses' testimonies are crucial to facilitate expert diagnoses.

(7) A witness, located about 1 mile from the accident site, observed the airplane circle the airport from south to north. He then saw it maneuvering at a low altitude between two hangars and heard a loud "pop" followed by the sound of the engine sputtering. (...)[NTSB Identification: CEN10FA130]

c) Enhance the authority of verdicts through the verbatim transcription of normative literature (e.g. regulations, operation manuals, etc.).

(8) However, 14 Code of Federal Regulations (CFR) 91.111(a) states that "no person may operate an aircraft so close to another aircraft as to create a collision hazard". In addition, 14 CFR 91.113 stipulates that the pilot of an overtaking airplane (in this case, the PA24) "shall alter course...to pass well clear" of the overtaken airplane. (...) [NTSB Identification: ERA11FA291A]

d) Hedge with scare quotes inaccuracies from lay witnesses and popularisations unnecessary in expert settings, thus segregating the lay audience from the community of experts (see also example 7).

(9) A witness working in a field observed the helicopter fly overhead and heard the rotor blades making "funny noises". Shortly after, the witness lost sight of the helicopter and observed a plume of smoke. (...) [NTSB Identification: CEN10LA558]

e) Mitigate negative criticism of the crew's or aviation personnel's behaviours, frequently through implicature: the negative comment is not expressed by the NTSB but indirectly inferred from the speech of actors and witnesses.

(10) The pilot then transmitted to the controller that he had gotten himself "a little out of whack" and that he was "just trying to straighten it out." Review of radar data revealed that, at the time the pilot transmitted this information to the controller, the airplane 
had begun to turn right and continued turning right for about 150 degrees before radar contact was lost. The airplane then struck a tree, a travel trailer, and a pickup truck, fatally injuring the pilot and one occupant of the trailer and seriously injuring the other occupant of the trailer. (...)[NTSB Identification: ERA11FA118]

f) Mark specific terms from the technical jargon of the community of practice (Wenger 1998).

(11) During the third and final aerobatic flight that day, after completing a loop maneuver called the "heart" maneuver, the pilot failed to recover from the nose-low descent before ground impact. (...) [NTSB Identification: ERA11FA214]

Institutional ethos is reinforced through detail disclosure because being able to provide narrative particulars is a sign of credibility and transparency, and at the same time backs up the final verdict by the Board just as any other of the pieces of evidence analysed in the course of the investigation (e.g. the wreck, the terrain, cabin voice recordings, the testimonies of crew, staff and witnesses, etc.). A high level of disclosure, nonetheless, may border on the flouting of Grice's quantity and relation maxims and mystify RC, which by principle should be direct and non-digressive. Detail is a persuasive device (it may condition judgement) that can be phrased as direct speech reflecting confidential conversation snippets from cabin voice recordings (see again 6 and 10) or domestic scenarios (12), and may uncover medical (13), penal (14) and sentimental (15) information useful to explain certain behaviours, and thus determine accident causes. Emphasis is mine in all instances.

(12) The pilot reported that 12 days prior to the accident flight, he had suffered a loss of a close family member. The pilot stated that after the accident, he realized that coping with this loss affected his ability to focus his attention and degraded the quality of his sleep in the days before the event. The pilot further stated that it had been more clear to him post accident, as his "sleep deprivation had become very obvious". (...) [NTSB Identification: WPR11FA103]

(13) The pilot had a medical history that included a traumatic brain injury following an accident that put him in a coma in 1993. This was accompanied with persistent cognitive deficits and frequent intermittent episodes of amnesia, severe chronic lung disease that required him to use supplemental oxygen to avoid hypoxia during periods of activity, and depression for which he had been receiving therapy. (...) [NTSB Identification: WPR11FA103]

(14) A review of law enforcement records revealed that the pilot had two alcohol and driving related convictions in 1994 and 1996. After the second conviction, the Federal Aviation Administration (FAA) requested that this pilot undergo psychiatric and neuropsychological evaluations, which did not formally result in a diagnosis of substance abuse or dependence, but noted that having the convictions gives an indication that the pilot does have problems with drinking and that alcohol consumption is an area of potential danger for him. (...) [NTSB Identification: WPR11FA103]

Obviously, detail may as well immerse the reader in the risk context, act as a mnemonic and entertain and sustain attention just as in medias res openings and multivocal direct speech reporting can do, but, above all, it didactically exposes the fuzziness of the 
public and private spheres, and the repercussions of private and apparently innocuous behaviours and decisions on the common safety and welfare.

(15) a. The pilot departed on a visual flight rules flight on a dark night, and family members reported that he had been drinking alcohol and was under emotional distress. (...)[NTSB Identification: WPR10FA305]

b. According to law enforcement personnel, during the 2 years preceding the accident, the pilot had gone through a divorce, the closure of his business, and most recently was anticipating arrest on a felony charge.

Additionally, about 1 month before the accident, a detective received a telephone call from a family member of the pilot, who expressed concern that the pilot was going to commit suicide based on remarks that the pilot had made; however, the family member later stated that the pilot recanted. (...) [NTSB Identification: ERA12FA483]

While it might appear that the voice of the NTSB's verdicts (supposedly omniscient and distal) clashes with the intimacy and rapport generated by plural (and at times conversational) storytelling, detail disclosure and the amusement of in medias res openings, the global effect turns out to be the opposite: these strategies serve to depict the NTSB as a flexible authority that hosts a number of other co-narrating voices, convergent with its final decisions and instrumental to approaching the audience to the notion and contexts of risk.

\section{CONCLUDING REFLECTION: IS RC AT RISK?}

The emotional hue of NTSB dockets and the varied range of resources materialising it are indeed out of the ordinary in a society where abridged technical documents are supposed to be distal and extremely concise. We have seen that, more than a lexical repertoire, the emotional prosody of NTSB dockets is grounded in rhetorical organisation, narrative focalisation (i.e. a plural co-constructed narrative convergent with the Board's voice) and the representation of speech (direct reporting). While the scarce emotional lexis found pivots around blame, repulsion and empathy, the proximal discourse generated by rhetoric and narrative establishes a tacit emotional prosody of curiosity, surprise and fear. Of curiosity, thanks to the in medias res openings in the accident narrative, which grab the reader's interest. Of surprise by means of the possible twists in the narrative denouement, as the accident events and/or the results of expert analyses unfold, as well as by the postponed verdict. Of fear because the use of detail, direct speech and deictic nearness makes readers see the risk much closer and probable than they had imagined.

Still we may wonder, political branding aside, whether these proximal discursive strategies really improve RC: their efficacy in terms of risk prevention remains uncertain and can only be determined by means of reception, ethnographic, cross-disciplinary and cross-cultural studies, because the definition and perception of risk is context- and culture-bound (Fischhoff \& Kadvany 2011).

We still know little about optimal RC in general, as the technical specialists' knowledge of risk is limited to their areas of expertise. Fishhoff and Kadvany (2011: 20) 
observe: "No one is expert in all aspects of any risk decision, much less all risks". Empiricism, though, does not seem to be the solution, as these authors also note (Fishhoff and Kadvany 2011: 94) that in their epistemic evaluations of risk, people 'have trouble using numbers' (i.e. statistics) and prefer words; the trouble is that appraisal terms such as 'likely' or 'rare' are too vague. What is clear is that NTSB dockets must confront two distinctive challenges that may endanger their RC nature: pragmatic conflict and the activation of unintended constructs. The former means avoiding flouting the Gricean maxims of quantity and relation, and preempting face-threatening acts derived from the trivialisation, owing to their videogame-like appearance, of the 3D accident animations accompanying many dockets and accessible with a hyperlink. They more often than not include cabin audio recordings with the voices of deceased crew members, which might be shocking, to say the least, for their families. The latter challenge stems from the 'selective exposure and attention' to some message components and their 'peripheral processing' (Sol Hart, 2014). If emotion does direct attention and individuals may understand a message differently or focus on different aspects of it, erroneous interpretations may arise and originate a 'boomerang effect' - the opposite result of what was originally intended. Logically, the chances of producing boomerang effects augment with diverse audiences.

Certainly, this study launches more questions than proposals, and answering them would require conducting longitudinal reception studies on different populations of addressees. Some of these questions opening up new research avenues could be: Do in medias res openings, multivocal direct speech reporting, and detail disclosure work as distracting elements and therefore as boomerang factors? Is the processing of direct speech implicatures (e.g. the blaming of crews and aviation personnel in quoted first-hand testimonies and specific word collocations and rhetorical structures) too peripheral? What author-intended implicit information goes unnoticed? What take-home message is the lay audience left with? How much informative and entertaining should RC be? Should dockets follow a simpler telling scheme with a more linear rhetorical structure and be cruder and less euphemistic in their depiction of the catastrophe? What unquestionably matters is that the NTSB has taken a first step to bridging a long-standing gap in engineering RC: the tendency to neglect human behaviours (Fischhoff and Kadvany 2011) because of their difficult quantification and to distrust those social sciences that take the human factor into account. Only time and interdisciplinary collaboration will tell whether this NTSB's attempt has been more perplexing than fruitful.

(C) Carmen Sancho Guinda, 2018

\section{REFERENCES}

Andrews, M., Squire, C. \& Tamboukou, M. (eds.) (2008). Doing narrative research. London: Sage.

Anthony, L. (2007). AntConc 3.2.1w. Retrieved from http://www.antlab.sci.waseda.ac.jp/software.html.

Bal, M. (1985). Narratology: Introduction to the theory of narrative. Toronto: University of Toronto Press.

Bearman, P., Faris, R. \& Moody, J. (1999). Blocking the future: New solutions for old problems in historical social science. Social Science History 23 (4), 501—533. 
Bednarek, M. (2008a). Emotion talk across corpora. London/New York: Palgrave Macmillan.

Bednarek, M. (2008b). Semantic preference and semantic prosody re-examined. Corpus Linguistics and Linguistic Theory 4 (2), 119-139.

Berkenkotter, C., Bhatia V.K. \& Gotti, M. (2012). Introduction. In Berkenkotter, C., V.K. Bhatia \& M. Gotti (eds.) Insights into academic genres. Bern: Peter Lang, 9-28.

Besley, J.C. \& McComas, K.A. (2014). Fairness, public engagement and risk communication. In Árvai, J. \& L. Rivers (eds.) Effective risk communication. London: Routledge, 108-123.

Bhatia, V.K. (2014). Worlds of written discourse: A genre-based view. London: Continuum.

Bloor, M. \& Bloor, T. (2007). The practice of Critical Discourse Analysis. An introduction. London: Hodder Arnold.

Boholm, Å. \& Corvellec, H. (2014). A relational theory of risk: Lessons for risk communication. In Árvai, J. \& L. Rivers (eds.) Effective risk communication. London: Routledge, 8-22.

Cap, P. (2013). Proximization: The pragmatics of symbolic distance crossing. Amsterdam: John Benjamins.

Chouliaraki, L. (2008). Mediation, text and action. In Bhatia, V.K., J. Flowerdew \& R.H. Jones (eds.) Advances in discourse studies. London: Routledge, 211-227.

Czarniawska, B. (2004). Narratives in social science research. London: Sage.

Elliot, J. (2005). Using narrative in social research. Qualitative and quantitative approaches. London: Sage.

Fairclough, N. (1993). Critical Discourse Analysis and the marketization of public discourse: The universities. Discourse and Society 4 (2), 133-168.

Fairclough, N. (2006). Language and globalisation. London: Routledge.

Fischhoff, B. \& Kadvany, J. (2011). Risk. A very short introduction. Oxford: Oxford University Press.

Harré, R. \& van Langenhove, L. (1999). Positioning Theory: Moral contexts of intentional action. Oxford: Blackwell.

Hawley, K. (2012). Trust. A very short introduction. Oxford: Oxford University Press.

International Civil Aviation Organisation (ICAO) (2006). Safety management manual (SMM). Doc. 9859 (1st ed.). Montreal: ICAO.

Kohler Riessman, C. (2008). Narrative methods for the human sciences. London: Sage.

Labov, W. \& Waletzky, J. (1967). Narrative analysis: oral versions of personal experience. In Helm, J. (ed.) Essays on the verbal and the visual arts. Seattle: University of Washington Press, $12-44$.

Machin, D. \& Mayr, A. (2012). How to do Critical Discourse Analysis. A multimodal introduction. London: Sage.

Martin, J.R. \& White, P.R.R. (2005). The Language of evaluation: Appraisal in English. London/New York: Palgrave/Macmillan.

Maynard, A. (2011). Risk = OMG x WTF! 2020 Science. Retrieved from http://2020science.org/ 2011/10/18/risk-omg-X-wtf/.

Neeley, L. (2014). Risk communication in social media. In Árvai, J. \& L. Rivers (eds.) Effective risk communication. London: Routledge, 143-164.

NTSB website http://www.ntsb.gov/.

NTSB Accident synopses by month. Retrieved from http://www.ntsb.gov/aviationquery/month.aspx.

Plutchik, R. (1980). Emotion - A psychoevolutionary synthesis. London: Longman.

Sancho Guinda, C. (2015). Digital vividness: Reporting aviation disasters online. In Bondi, M., S. Cacchiani \& D. Mazzi (eds.). Discourse in and through the media: Recontextualizing and reconceptualizing expert discourse. Newcastle upon Tyne: Cambridge Scholars, 187-212. 
Shaver, P.R., Murdaya, U. \& Fraley, R.C. (2001). Structure of the Indonesian emotion lexicon. Asian Journal of Social Psychology 4, 201-224.

Sol Hart, P. (2014). Boomerang effects in risk communication. In Árvai, J. \& L. Rivers (eds.) Effective risk communication. London: Routledge, 304-318.

Stubbs, M. (2001). Texts, corpora, and problems of interpretation: A response to Widdowson. Applied Linguistics 22, 149-172.

Swales, J.M. (1990). Genre analysis: English in academic and research settings. Cambridge: Cambridge University Press.

Tardy, C.M. (2016). Beyond convention: Genre innovation in academic writing. Ann Arbor, MI: University of Michigan Press.

Tuler, S.P. \& Kasperson, R.E. (2014). Social distrust and its implications for risk communication. In Árvai, J. \& L.Rivers (eds.) Effective risk communication. London: Routledge, 91-107.

Watt Smith, T. (2015). The book of human emotions. London: Profile Books.

Wenger, E. (1998). Communities of practice: Learning, meaning and identity. Cambridge: Cambridge University Press.

Xiao, R. \& McEnery, T. (2006). Collocation, semantic prosody and near synonymy: A crosslinguistic perspective. Applied Linguistics 27 (1), 103-129. doi: 10.1093/applin/ami045.

Xie, X., Wang, M., Zhang, R., Li, J.\&Yu, Q. (2011). The role of emotions in risk communication. Risk Analysis, 31 (3), 450-465.

Zhang, Y. \& K.L. O'Halloran (2014). From popularization to marketization: The hypermodal nucleus in institutional science news. In Djonov, E. \& S. Zhao (eds.) Critical multimodal studies of popular discourse. New York, NY: Routledge, 160-177.

Zwickle, A. \& Wilson, R.S. (2014). Construing risk. In Árvai, J. \& L. Rivers (eds.) Effective risk communication. London: Routledge, 143-164.

\section{Article history:}

Received: 08 August 2017

Revised: 10 September 2017

Accepted: 15 September 2017

\section{For citation:}

Guinda, Carmen Sancho (2018). The Emotional Prosody of U.S. Fatal Air-Accident Dockets Online: Risking Risk Communication? Russian Journal of Linguistics, 22 (1), 126-143. doi 10.22363/2312-9182-2018-22-1-126-143.

\section{Bionote:}

CARMEN SANCHO GUINDA is Senior Lecturer in the Department of Applied Linguistics at the Universidad Politécnica de Madrid, where she teaches English for Academic and Professional Communication at the school of Aerospace Engineering and in-service seminars for engineering teachers willing to undertake English-medium instruction. Her research focus is the interdisciplinary study of academic and professional discourses and genres and innovation in the learning of academic competencies. Her most recent publications are Stance and Voice in Written Academic Genres (Palgrave, 2012), co-edited with Ken Hyland, Narratives in Academic and Professional Genres (Peter Lang 2013), co-edited with Maurizio Gotti, Interpersonality in Legal Genres (Peter Lang 2014), co-edited with Ruth Breeze and Maurizio Gotti, and Essential Competencies for English-medium University Teaching (Springer 2017), co-edited with Ruth Breeze. She is co-editor of the online journal Language Value and member of the editorial boards of Journal of English for Academic Purposes, Ibérica, and Revista de Lingüística y Lenguas Aplicadas. Contact information: e-mail: carmen.sguinda@upm.es 


\title{
FINANCE AND ACKNOWLEDGEMENTS:
}

This article has been written within the framework of the coordinate research project 'Emo Fundett' (FFI2013-47792-C2-1-P), funded by the Spanish Ministry of Economy and Competitiveness. My thanks to its principal investigator, Prof. Laura Alba Juez, and the rest of fellow researchers.

DOI: $10.22363 / 2312-9182-2018-22-1-126-143$

\section{ЭМОЦИОНАЛЬНАЯ ПРОСОДИЯ В ОН-ЛАЙН ИНСТРУКЦИЯХ В СИТУАЦИИ АВИАКАТАСТРОФ: КОММУНИКАЦИЯ В ОБСТАНОВКЕ РИСКА}

\author{
Кармен Санчо Гинда \\ Мадридский политехнический университет \\ Calle Ramiro de Maeztu, 7, 28040 Madrid, Испания
}

Коммуникация в ситуации риска является и рациональной, и эмоциональной (Fischhoff $\&$ Kadvany 2011, Boholm \& Corvellec 2014). Современные исследования доказали, что эмоции действительно влияют на восприятие опасности и риска и выполняют функцию «медиаторов» (Xie et al. 2011) в принятии решений. Данная работа посвящена эмоциям в текстах обращений Национального транспортного комитета по безопасности США (NTSB), которые влияют на настроение и поведение широкой и разноплановой аудитории и таким образом повышают степень безопасности. С этой целью был проанализирован электоронный корпус из 500 инструкций о смертельной опасности на авиационном транспорте (с 2010 по 2015 г.), ежегодно публикуемых на сайте NTSB. Тексты подобных инструкций, содержащих эмоциональный компонент восприятия риска и опасности, представляют собой уникальный жанр, поскольку информативная яркость и насыщенность активизируют процессы памяти, суждений и принятия решений. В качестве отправной точки берется понятие «дискурсивной просодии» (Stubbs 2001), а в качестве теоретической базы используются нарратология, корпусная лингвистика, критический дискурс-анализ, а также теории проксимизации (Сар 2013) и позиционирования (Harré \& van Langenhove 1999). В данной статье показано, что эмоциональная просодия в оповещении о рисках является более риторической, чем лексической, и важную роль играют нарративные стратегии акцентирования и речевой репрезентации. В заключении делаются предположения о возможных последствиях злоупотреблений эмоциональной составляющей в коммуникации в ситуации риска.

Ключевые слова: коммуникация в ситуации риска, эмоциональная просодия, проксимизация, позиционирование, нарративное акцентирование, регистраторы авиакатастроф онлайн, Наииональный Транспортный комитет США по Безопасности

\section{История статьи:}

Дата поступления в редакцию: 8 августа 2017

Дата принятия к печати: 15 сентября 2017

\section{Для цитирования:}

Guinda, Carmen Sancho (2018). The Emotional Prosody of U.S. Fatal Air-Accident Dockets Online: Risking Risk Communication? Russian Journal of Linguistics, 22 (1), 126-143. doi 10.22363/2312-9182-2018-22-1-126-143. 


\section{Сведения об авторе:}

КАРМЕН САНЧО ГИНДА - доцент кафедры прикладной лингвистики Мадридского политехнического университета. Преподает английский язык в сфере научной и профессиональной коммуникации в школе космической инженерии, проводит семинары для преподавателей технических наук. Сфера научных интересов - междисциплинарное исследование научного и профессионального дискурса, жанров и инноваций в формировании научной компетенции. Последние публикации: Stance and Voice in Written Academic Genres (Palgrave, 2012) (соредактop - Maurizio Gotti), Narratives in Academic and Professional Genres (Peter Lang 2013), Interpersonality in Legal Genres (Peter Lang 2014) (соредакторы - Ruth Breeze, Maurizio Gotti), Essential Competencies for English-medium University Teaching (Springer 2017) (соредактор - Ruth Breeze). Она является также соредактором электронного журнала Language Value и членом редколлегий журналов Journal of English for Academic Purposes, Ibérica, Revista de Lingüistica y Lenguas Aplicadas. Контактная информация: e-mail: carmen.sguinda@upm.es

\section{ФИНАНСИРОВАНИЕ И БЛАГОДАРНОСТИ:}

Статья является частью исследовательского проекта EMO-FUNDETT (Эмоции и язык в действии: эмотивная оценка функций разных текстов и рабочих контекстов) за номером FFI201347792-С2-1-Р. Этот проект финансируется Министерством экономики и конкуренции Испании. Автор выражает благодарность руководителю исследовательской группы Профессору Лауре Альба-Хуэс и коллегам. 